\title{
Distributed System of Dams for Flood Protection of Urban Land to Ensure Sustainable Development
}

\author{
Mikhail Fedorov ${ }^{1}$, Vladimir Badenko ${ }^{1, *}$, Vladimir Maslikov ${ }^{1}$ and Alexander Chusov ${ }^{1}$ \\ ${ }^{1}$ St. Petersburg State Polytechnical University, 195251, Politekhnicheskaya, 29, Saint-Petersburg, \\ Russia
}

\begin{abstract}
The article considers innovative materials and structures for multipurpose flood protection self-regulated dams. Russian and foreign experiences in flood consequence, as well as conceptions for protection of urban land in the context of climate change are analyzed. Method for flood protection is proposed and is proved by creation of distributed system of self-regulated flood-control distributed system of dams in a river basin.
\end{abstract}

\section{Introduction}

Flood protection is one of the main development problems of modern society, related to environment. In conditions of evidencing trend to global climate change the goal becomes even more important, as well as a concern rate of stream flow.

From the economic point of view flooding was always considered a major natural disaster. Observed climate change was led to sharp increase frequency of heavy flooding across the World, which is accompanied by increasing of economic losses and a number of injured persons. Rates of growth of economic losses are comparable with increasing of gross output across the globe. Showery flooding causes particularly drastic consequences. Primary hazard consists in their abruptness and sharp increasing amount of stream runoff, that is in a great deal exceed volume river flow of spring tide.

In last decades there were several heavy flooding in Europe which connected with longduration of heavy rain. From the period 1950 to 2006, 12 flooding took place with large human losses. Frequently flooding covered entire regions, thus, 2002 was recorded by number of countries, which territories were simultaneously flooded (Austria, Czech Republic, France, Germany, Hungary, Rumania). Moreover, flooding, that covered territories of several countries, happened in other periods: Netherlands, Belgium, France and Germany (1993 and 1995), Czech Republic, Poland and Germany (1997), France, Italy and Poland (2010), Germany and Italy (2012). Approximately one fifth part of European cities with population more than 100000 citizens per city are exposed to flash flood, generated by extremes precipitations [1-6].

\footnotetext{
* Corresponding author: vbadenko@gmail.com
} 
The issues of rain floods are permanent exist in Russia, and in consequence of climate change it is expected to further aggravation [7]. Extreme flood, generated by heavy rain, were observed in the north Caucasus, at the coast of the Black sea, in the Russian Far East, etc. In the regions with monsoon climate, that is typical for Russian's Far East, flash rain flood covers great territories. Flood event in 2013, in consequence of heavy rains, continued approximately about two months inundated territories of the Far East and northern-east China [8]. Going forward in the middle of the 21 Century precipitation extremeness in summer period in mountainous area of the Caucasus, in Siberia and in the Far East is able to increase, therefore frequency and value of rainfall flood will grow up [9].

Nowadays, flood protection of territory is carried out according risk-based flood management as a system approach that assesses and compares the structural and nonstructural (management and administration) ways to pursue the optimal ameliorating effects $[4,10]$. Common flood protection measures are orientated on existing situation and does not take into account its uncertainty in the nearest future and further such as urbanization development, climate change and land utilization (deforestation, wetland reduction), etc. Thus, cost-expensive actions occur inefficient. In this respect a conception of flood mitigation is changing from protective measures to risk management. In particular, in EU a Directive was adopted [11] by flood risk management, which connected with European Water Framework Directive on management of river basin water sources [12]. Flood risk management in dynamical conditions of climate change is started with river basin spatial planning of water, agricultural and forestry, settlement, etc., and then assessment of flood risk area and corresponding damages is made. Based on the evidence found suitable protection systems from flooding in river basins are developed.

In Russia, as in other countries, regulation of maximum runoff by great reservoirs [13] is widely used and effective method for flood mitigation. Corresponding dams are located on main stream, and can protect areas located downstream. The objective of this paper is to develop a method for design of distributed system of self-regulated dams for flood protection of urban land to ensure sustainable development.

\section{Materials and methods}

In recent times, there is a tendency to build on the mainstream low-pressure multipurpose dam with reservoir (DWR) (with minimal operational level and small flood control capacity) for the purpose of reduction land inundation. In conditions decreasing of adjustability extreme of water flow, additional required flood-prevention reservoir is possible to place on local inflows. In this case large areas can be protected in flood plain, upstream and local inflows, which percent can put together up to $50 \%$ on the part of total inundated area in the river basin, due to spatial distribution of flood protection regulating reservoir. This approach accords with modern strategy of flood risk decreasing by management of flood discharge for all river basins by distributed system of DWRs with minimal impact on the environment $[14,15]$.

For specific river basins zoning of economic development of territories and flooding areas are carried out, allocation scheme of flood-control DWRs is developed, whose quantity, type and parameters are chosen depending on physical and climatic, social and economic, environmental conditions, requirements of environmental protection, etc. For this purpose there is necessity to development of mathematical models, describing natural and economic situation, operating mode of flood-control DWRs, providing a flood risk assessment and planning activities on risk reduction.

For example, a system of non-energy flood-control DWRs is created in a river basin, locating in riverhead of a base stream and local inflows (fig. 1). 


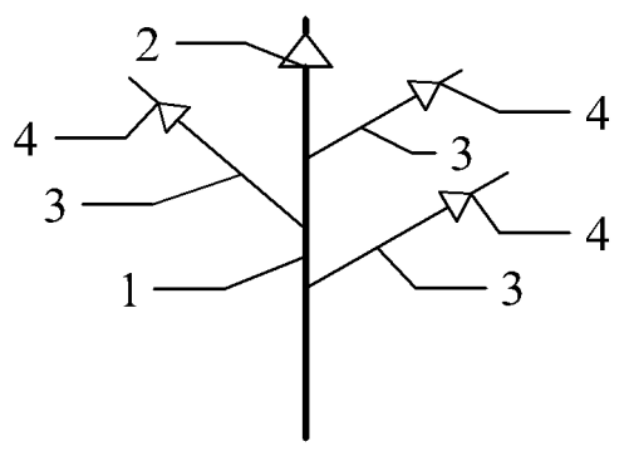

Fig. 1. The flood control waterworks in a river basin. 1 - the main watercourse, 2 - reservoir in the upper reaches of the river, 3 - side confluents, 4 - flood-control waterworks.

Previously executed researches showed reasonability of creating reservoirs on local inflows by way of temporary filling self-regulatory storages [16]. A DWR culvert is performed with uncontrolled spillway without the use of flow regulating valve, which increase reliability of operation and reduce the cost of maintenance. During accumulation of flood discharge this type of reservoir bed is flooded in a short-time, and from its selfdischarge to the next flood keeps dry in natural state.

Flood-control DWR can be performed in form of combination structure of regulating culvert. In this DWR the passing discharge is carried out on two stages: downstream is through bottom discharge, which works in free-flow mode, and upstream is through overflow spillway (Fig. 2).

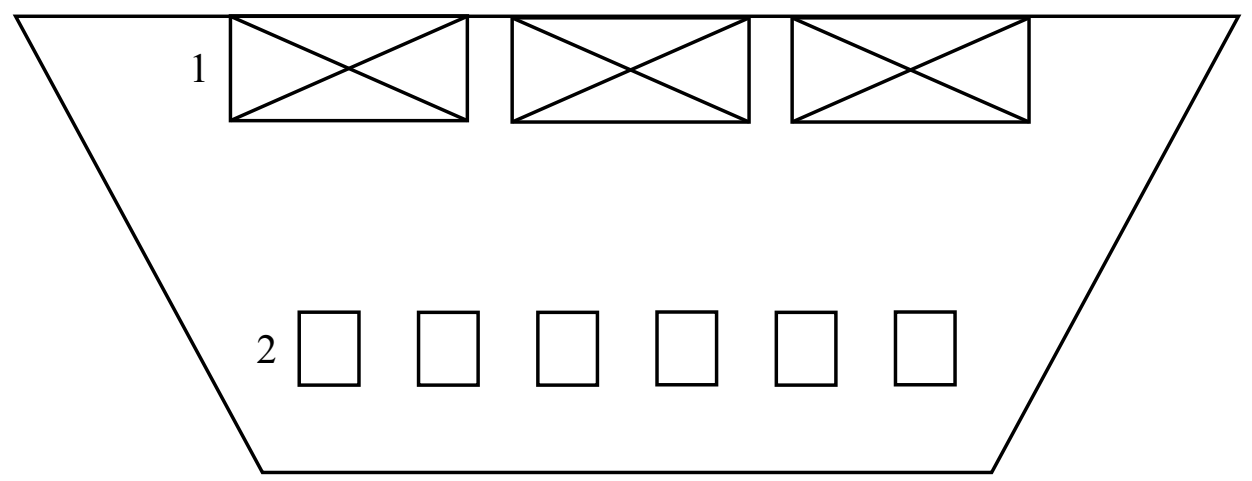

Fig. 2. The discharge holes in dam: 1 - surface spillway, 2 - bottom spillway

For selected scheme of flood management on watershed algorithms were developed and mathematical models of operational mode of flood-control DWRs in local inflows were implemented in software, which allowing to vary by parameters of discharge structures for determination of regulated flow in tail-water, watermarks in headrace, water volume at accumulation of flood control discharge, areas and duration of flooding lands [17-19].

The calculation of flood discharge volume, accumulated in reservoir at the moment $t$, is carried out by balance method:

$$
V(t)=V(t-\Delta t)+[Q 1(t)-[Q 2(t)+Q 3(t)+Q 4(t)]] \cdot \Delta t,
$$

where: $\mathrm{V}(\mathrm{t})$ - volume of water in a reservoir at time $\mathrm{t}, \mathrm{m} 3 ; \mathrm{Q} 1(\mathrm{t})$ - water flow entering a reservoir, m3/s; Q2(t) - water discharge to a downstream, m3/s; Q3 $(\mathrm{t})$ - loss of water by 
evaporation from surface of a reservoir, m3/s; Q4(t) - seepage water discharge, m3/s; $\mathrm{t}$ time, s. $\Delta \mathrm{t}-$ time step, s.

For DWRs in local inflows is provided a realization of main environmental requirements. Preservation of flood inundation processes is dammed escapade discharge in tail-water of DWR that should comply of flood probability of $10 \%$; conservation of nature ecosystems by their temporary flooding is the maximum water level in headrace of DWR does not exceed of acceptable level.

\section{Results and discussion}

As an example an operational mode of flood-control DWR was considered [15]. The dam with 10 bottoms and 3 open spillways was analyzed in one of local inflow of river basin of the river Selemdzha in the Far East of Russia, where the most frequently catastrophic floods in Russia are usually registered.

In figure 3 calculation results of water discharge in tail-water DWR is shown. Peak water discharge $1 \%$ of probability is decreased approximately on one third, that is reach to rate of probability discharge $10 \%$, which is allowed to preserve natural flood and inundation processes, but at the time, avoided catastrophic flooding.

These results were obtained with special software developed. The food hydrograph analized is one of typically observed in this point on the river.

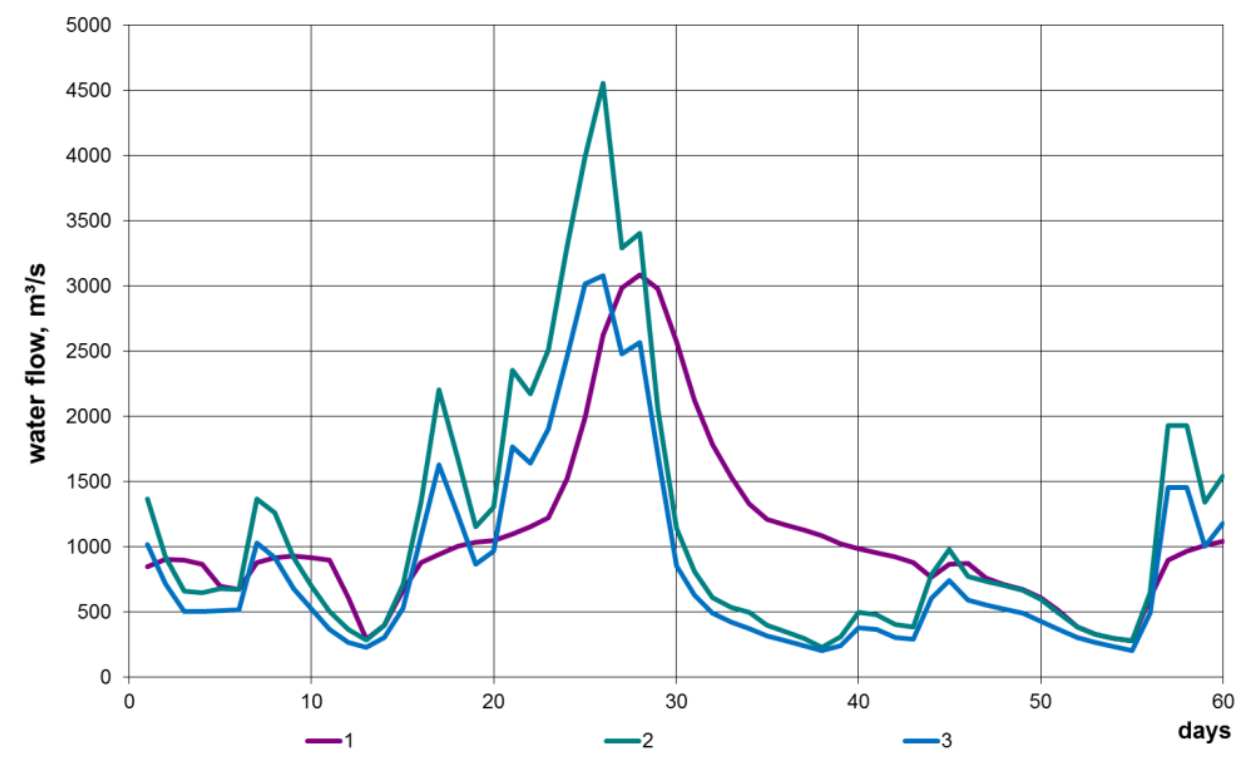

Fig. 3. Changes of water flow in the downstream of DWS

1 - the regulated discharge to the downstream, 2 - the natural flow with $1 \%$ probability,

3 - the natural flow with $10 \%$ probability.

In Figure 4 calculated changes of area and time of flooding of landscapes in the river basin obtained using software developed are shown. 


\section{TPACEE-2016}

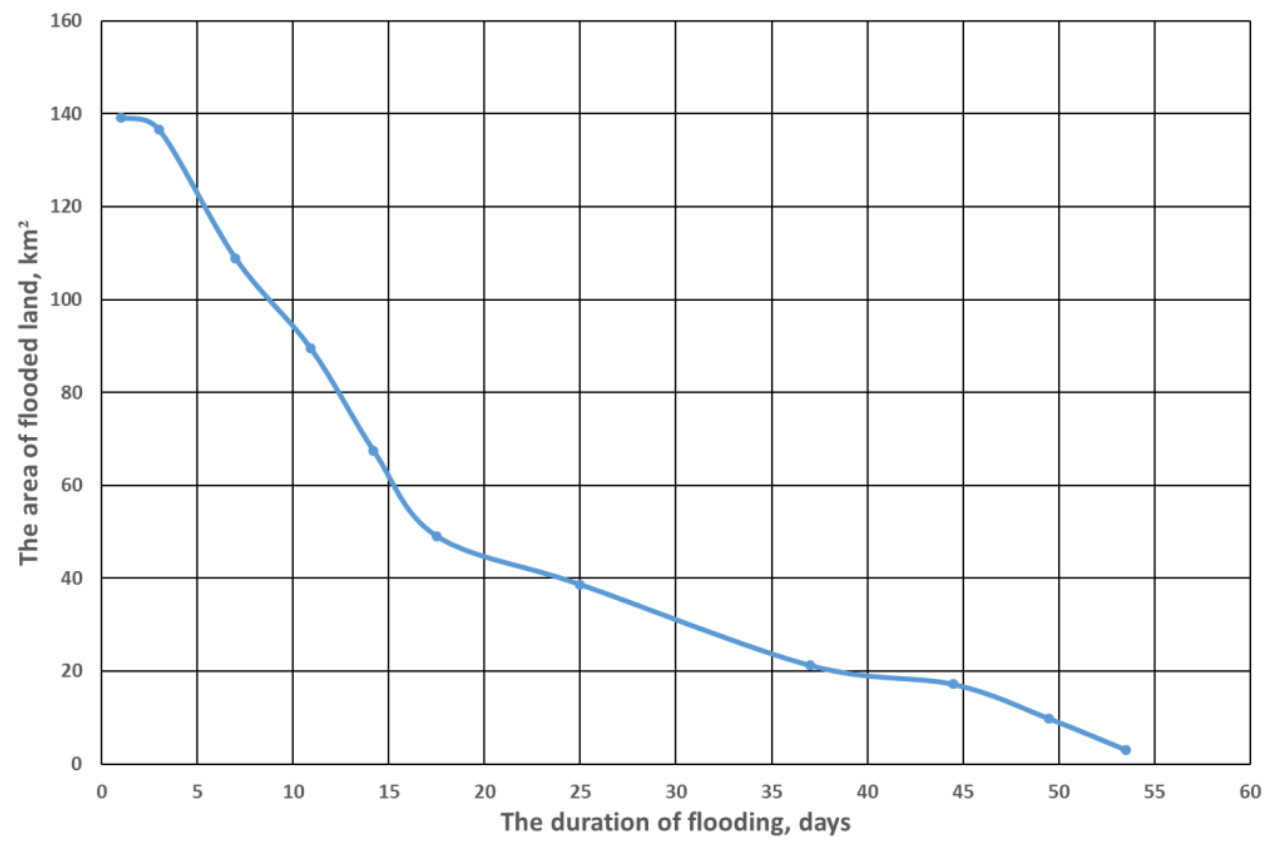

Fig. 4. The area and duration of land flooding

Conservation assessment of ecosystem biodiversity was made on temporary flooded lands with use of non-decrease criteria of biodiversity, as well as relation natural and manmade ecosystems [20]. It is shown that DWR is corresponded to requirements of environmental safety. It should be noted, that areas of flooding in this example was defined based on paper maps.

At the present time, methodologies for modelling with use of GIS are developed [2124]. In Figure 5 a part of satellite image of river basin in cross-section of flood-control DWR and flood hazard area corresponding to water plane of flood passing with different probability, designed with use of digital elevation model in GIS environment, is shown.

Using GIS-modeling allows considering variants of regulation for flood discharges using different DWR parameters with detail analysis of potential flooding areas in upstream and downstream of DWRs taking into account both social-ecological-economical aspects and climate changes. This approach can solve problems with population growth, urbanisation and climate change which represent significant pressures on sustainable urban development, requiring flood events managers to consider a wider array of management options that account for economic, social and environmental factors using modeling in GIS environment [25-31]. 

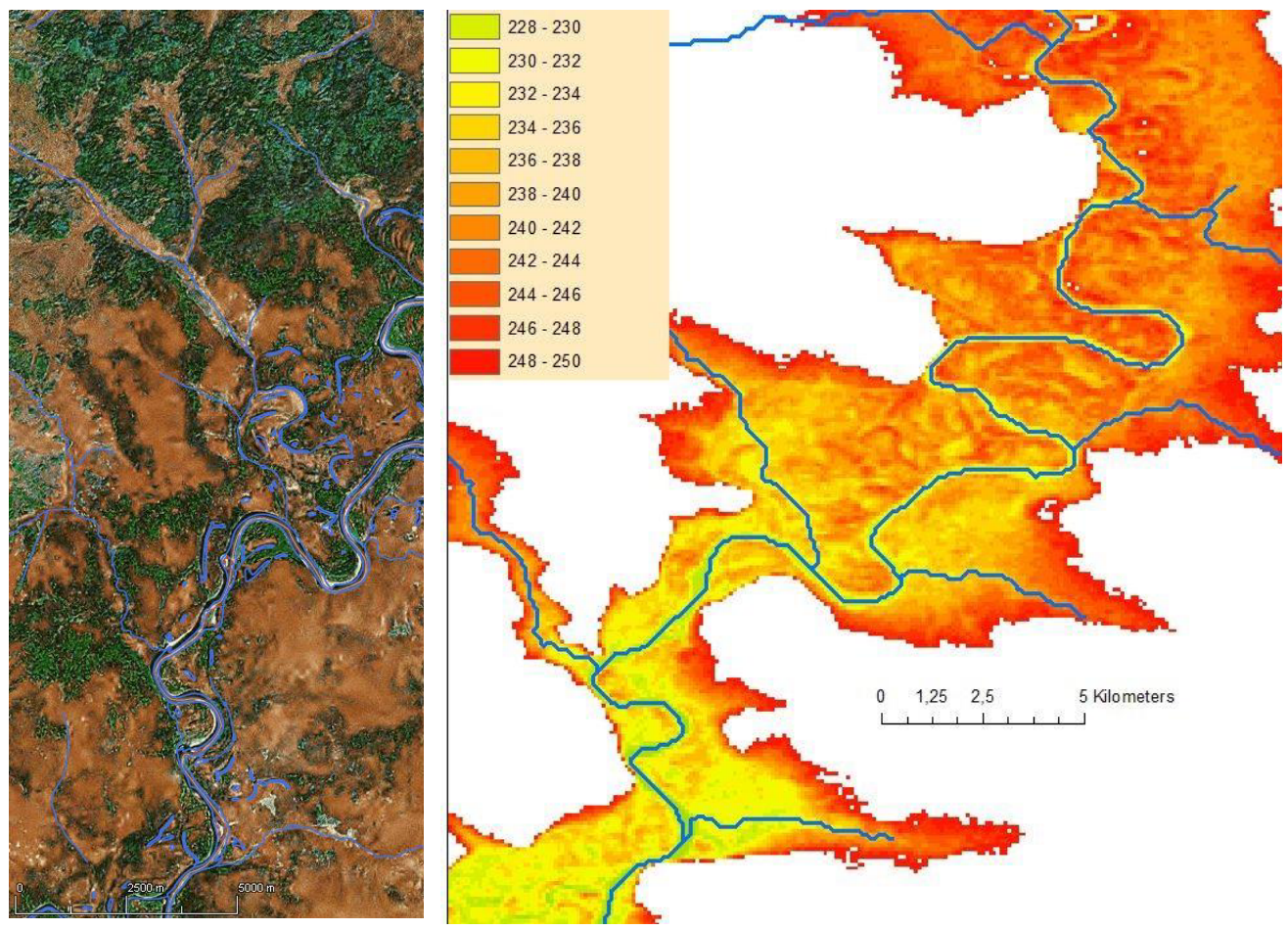

Fig. 5. The basin for research using GIS technologies. On the left: remote sensing data. On the right: digital elevation model (in the legend - elevations in meters).

\section{Conclusions}

Management of flood discharge of a river basin with distributed DWR with minimal impact on the environment was explained. Mathematical models for operation modes of flood protection DWR on local inflow with unregulated culvert in according with requirements of environmental safety were designed and were implemented.

Operation modes of flood protection DWSs were defined at regulation of peak flows, providing protection of natural flood-inundable processes, as well as biodiversity on temporary flooded areas. Using GIS-technologies the flooding areas were defined in according with water plane by passing of flood of different probability. Detention reservoirs are structural measures for the defense from flash flood events. Proposed approach can solve the problem of flood protection of urban land to ensure sustainable development.

\section{Acknowledgements}

This work is supported by the Russian Science Foundation under grant № 16-17-00050

\section{References}

1. S. Le Roy, R. Pedreros, C. André, F. Paris, S. Lecacheux, F. Marche, C. Vinchon, Natural Hazards and Earth System Sciences, 15, 2497-2510 (2015)

2. N.W. Arnell, S.N. Gosling, Climatic Change, 134, 387-401 (2016)

3. J. Hall, et al, Hydrology and Earth System Sciences, 18, 2735-2772 (2014) 
4. J. Ran, Z. Nedovic-Budic, Environment and Urban Systems, 57, 68-79 (2016)

5. A.H. Thieken, H. Kreibich, M. Müller, B. Merz, Hydrological Sciences Journal, 52, 1016-1037 (2007)

6. Z.W. Kundzewicz, N. Lugeri, R. Dankers, Y. Hirabayashi, P. Döll, I. Pińskwar, T. Dysarz, S. Hochrainer, P. Matczak, Mitigation and Adaptation Strategies for Global Change, 15, 641-656 (2010)

7. Y.L. Vorob'ev, V.A. Akimov, Y.I. Sokolov, Katastroficheskie navodneniya nachala XXI veka: uroki $i$ vyvody (DEHKS-PRESS Ltd., Moscow, 2003)

8. S.A. Shlyakov, et al, Gosudarstvennyj doklad «O sostoyanii zashchity naseleniya $i$ territorij Rossijskoj Federacii ot chrezvychajnyh situacij prirodnogo i tekhnogennogo haraktera v 2013 godu» (Russian Emergencies Ministry, Moscow, 2014)

9. G.V. Alekseev, et al, Vtoroj ocenochnyj doklad Rosgidrometa ob izmeneniyah klimata $i$ ih posledstviyah na territorii Rossijskoj Federacii: obshchee rezyume (Rosgidromet, Moscow, 2014)

10. A.B. Avakyan, M.N. Istomina, Power Technology and Engineering, 35, 89-93 (2001)

11. C. Butler, N. Pidgeon, Environment and Planning C: Government and Policy, 29, 533547 (2011)

12. J. Verschuuren, J. McDonald, Transnational Environmental Law, 1, 355-379 (2012)

13. V.I. Danilov-Daniliyan, et al, Reki i ozera mira (Encyclopedia Ltd., Moscow, 2012)

14. T. Petrow, B. Merz, Journal of Hydrology, 371, 129-141 (2009)

15. M.P. Fedorov, V.I. Maslikov, Bulletin of the Russian Academy of Sciences, Energetics, 4, 47-52 (2013)

16. Yu.S. Vasil'ev, S.N. Dobrynin, V.I. Maslikov, T.S. Tikhonova, I.G. Kudryasheva, Hydrotechnical Construction, 34, 122-129 (2000)

17. R.J. Batalla, C.M. Gomez, G.M. Kondolf, Journal of Hydrology, 290, 117-136 (2004)

18. M.P. Fedorov, V.V. Elistratov, V.I. Maslikov, G.I. Sidorenko, A.N. Chusov, V.P. Atrashenok, D.V. Molodtsov, A.S. Savvichev, A.V. Zinchenko, Power Technology and Engineering, 49, 33-39 (2015)

19. V.V. Elistratov, V.I. Maslikov, G.I. Sidorenko, Power Technology and Engineering, 49, 6-10 (2015)

20. M.P. Fedorov, A.G. Bogolyubov, V.I. Maslikov, Hydrotechnical Construction, 29, 353-357 (1995)

21. N.V. Aref'ev, V.L. Badenko, G.K. Osipov, Power Technology and Engineering, 32, 660-663 (1998)

22. N. Arefiev, V. Terleev, V. Badenko, Procedia Engineering, 117, 39-44 (2015)

23. D. Kurtener, V. Badenko, Journal of the Brazilian Computer Society, 6, 26-32 (2000)

24. D. Kurtener, V. Badenko, Geomatics Info Magazine, 15, 76-79 (2001)

25. L. Willuweit, J.J. O'Sullivan, Water Research, 47, 7206-7220 (2013)

26. M. Deakin, A. Reid, Sustainable Cities and Society, 10, 39-48 (2014)

27. H. Wheater, E. Evans, Land Use Policy, 26, 251-264 (2009)

28. C. Damodaram, M.H. Giacomoni, C.P. Khedun, H. Holmes, A. Ryan, W. Saour, E.M. Zechman, Journal of the American Water Resources Association, 46, 907-918 (2010)

29. M. Brilly, M. Polic, Natural Hazards and Earth System Science, 5, 345-355 (2005)

30. T. Grothmann, F. Reusswig, Natural Hazards, 38, 101-120 (2006)

31. E.J. Plate, Journal of Hydrology, 267, 2-11 (2002) 